\title{
Phosphorus Fractions and Their Transformations in Entisol
}

\author{
Alessandra Mayumi Tokura Alovisi ${ }^{1}$, Alves Alexandre Alovisi ${ }^{1}$, Ademar Pereira Serra ${ }^{2}$, Luciene Kazue Tokura ${ }^{3}$, \\ Livia Maria Chamma Davide ${ }^{1}$, Elaine Reis Pinheiro Lourente ${ }^{1}$, Robervaldo Soares da Silva ${ }^{1}$, Willian Isáo Tokura ${ }^{4}$, \\ Daiana Alovisi de Souza ${ }^{5} \&$ Gilson Domingos do Mar $^{1}$ \\ ${ }^{1}$ Faculdade de Ciências Agrárias, Universidade Federal da Grande Dourados, Dourados, MS, Brazil \\ ${ }^{2}$ Embrapa Gado de Corte, Campo Grande, Mato Grosso do Sul, Brazil \\ ${ }^{3}$ Universidade Estadual do Oeste do Paraná, Cascavel, PR, Brazil \\ ${ }^{4}$ Universidade Federal de Goiás, Goiânia, GO, Brazil \\ ${ }^{5}$ Universidade Federal de Mato Grosso do Sul, Campo Grande, MS, Brazil \\ Correspondence: Alessandra Mayumi Tokura Alovisi, Faculdade de Ciências Agrárias, Universidade Federal da \\ Grande Dourados, Dourados City, State of Mato Grosso do Sul, Brazil. E-mail: alessandraalovisi@ufgd.edu.br
}

Received: September 28, 2018

doi:10.5539/jas.v11n1p485
Accepted: November 2, $2018 \quad$ Online Published: December 15, 2018

URL: https://doi.org/10.5539/jas.v11n1p485

This study was financed in part by the Coordenação de Aperfeiçoamento de Pessoal de Nivel Superior-Brasil (CAPES)-Finance Code 001.

\begin{abstract}
The availability of phosphorus in the soil is a factor that directly interferes with its absorption by plants. This availability can be influenced by the texture, dose of the phosphate fertilizer and the time of contact with the soil. This study aimed to quantify the organic and inorganic fractions of $\mathrm{P}$ accumulated in a sandy soil receiving doses of phosphorus, incubated and grown with rice. The experimental design was a completely randomized design, in a $4 \times 3$ factorial scheme, with four replicates, and four $\mathrm{P}$ doses $\left(0,80,240\right.$, and $\left.410 \mathrm{mg} \mathrm{dm}^{-3}\right)$ and three evaluation times (before sowing, after harvest, and incubated). Soil samples were collected before, after incubation, and after rice harvesting, and then submitted to a chemical fractionation of $\mathrm{P}$. P fractions were influenced by soil collection times. The inorganic fractions prevailed before sowing and after incubation, and the organic fractions prevailed after harvest. Phosphate fertilization favored mineralization of organic $\mathrm{P}$ and redistributes the inorganic and organic $\mathrm{P}$ fractions, between labile and non-labile compartments. The application of phosphate fertilizer in an Entisol Quartzipsamment contributes to the accumulation of inorganic fractions, especially in the most labile fractions.
\end{abstract}

Keywords: sandy soil, sequential fractionation, organic phosphorus, inorganic phosphorus

\section{Introduction}

Over the las few decades, agriculture has expanded extraordinarily in the region of Brazilian Cerrado. This expansion led to an increase in land occupation of sandy soils. Sandy soils have historically been considered marginal and with low agricultural capability, but with the possibility of adopting new management technologies advocated by sustainable production systems. These soils have started to attract a greater economic interest on the part of the farmers (Kluthcouski \& Cordeiro, 2016).

The main class of sandy soils in Brazil is Entisol Quartzipsamment, which occupies $11 \%$ of the country's territory (Spera, Reatto, Martins, Correia, \& Cunha, 1999). Its clay content is of less than $20 \%$ and the minimum sand content is $50 \%$, which makes it susceptible to water erosion and nutrient losses due to leaching, since it has low water retention capacity, high percolation, and water infiltration rates, besides low cation exchange capacity (CEC), low natural fertility, low $\mathrm{pH}$, high aluminum content, and low organic matter content.

The adequate supply of phosphorus (P) to crops in sandy soils is always a challenge since plants normally require low phosphorus levels compared to other nutrients such as nitrogen and potassium, but there is a need to apply high doses of phosphate fertilizers to increase crop productivity. However, nutrient amounts, including P, 
are not always defined based on technical criteria and, therefore, accumulation of excess $\mathrm{P}$ and fraction modifications must be expected.

Despite the importance of organic phosphorus, which in unfertilized systems is the main source of P-available to plants, its forms are not quantified by routine chemical analyses and they are disregarded since there are no direct methods for their quantification in the soil (Turner, Cade-Menun, Condron, \& Newman, 2005). Using several methodologies, different studies have been developed to quantify and understand the dynamics of $\mathrm{P}$ forms and fractions (Po and Pi) (Alovisi et al., 2011, 2016, 2018; Costa et al., 2016).

Thus, the quantification of soil $\mathrm{P}$ fractions through the fractionation method is useful in the investigation of soil $\mathrm{P}$ dynamics. The P fractionation method proposed by Hedley, Stewart, and Chauhan (1982) has been used to describe the transformations that occur with $\mathrm{P}$ in the soil, involving sequential extraction of labile, poorly labile, and non-labile forms, whereby inorganic and organic forms are separated according to their availability to plants. The knowledge of $\mathrm{P}$ dynamic can help in guide soil fertilizer recommendation for crops.

Thus, the objective of this study was to quantify the organic and inorganic fractions of $\mathrm{P}$ accumulated in sandy soil which received doses of phosphorus, underwent incubation and cultivation with rice.

\section{Material and Methods}

The experiment was carried out in a greenhouse using soil samples classified as Entisol Quartzipsamment (Soil Survey Staff, 2014), with sandy texture, kaolinitic, collected in the city of Itumirim-MG (Brazil), in the depth layer of 0 to $0.20 \mathrm{~m}$, under native vegetation (Cerrado biome).

After collection, the soil sample was prepared and submitted to physical, chemical, and mineralogical analyses. The physical analysis involved the determination of grain size composition of the air-dried fine soil (ADFS) fraction by the pipette method. Chemical analyses included $\mathrm{pH}$, sorption complex, organic $\mathrm{C}$, and micronutrients. P availability was evaluated by Mehlich-1 (Claessen, 1997) and ion exchange resin (Raij \& Feitosa, 1980). Total free $\mathrm{Fe}$ oxides and less crystalline $\mathrm{Fe}$ oxides in clay fraction were obtained by means of dithionite-citrate-sodium bicarbonate $\left(\mathrm{Fe}_{\mathrm{d}}\right)$ (Mehra, 1960) and ammonium acid oxalate $\left(\mathrm{Fe}_{\mathrm{o}}\right)$ (Schwertman, Kodama, \& Fisher, 1986), respectively. Oxides of sulfuric attack in ADFS samples were determined according to Vettori (1969), with modifications by Claessen (1997). Gibbsite and kaolinite were quantified in the deferrified (de-ironed) clay fraction by differential thermal analysis (Table 1).

The values found in the analyses were: $\mathrm{pH}$ in water: 5.0; $\mathrm{Al}^{+3}\left(\mathrm{mmol}_{\mathrm{c}} \mathrm{dm}^{-3}\right): 9.0 ; \mathrm{Ca}^{+2}\left(\mathrm{mmol}_{\mathrm{c}} \mathrm{dm}^{-3}\right): 4.0 ; \mathrm{Mg}^{2+}$ $\left(\mathrm{mmol}_{\mathrm{c}} \mathrm{dm}^{-3}\right): 1.0 ; \mathrm{K}^{+}\left(\mathrm{mg} \mathrm{dm}{ }^{-3}\right): 23.0 ; \mathrm{H}^{+}+\mathrm{Al}^{3+}\left(\mathrm{mmol}_{\mathrm{c}} \mathrm{dm}^{-3}\right): 45.0 ;$ P-Mehlich-1 $\left(\mathrm{mg} \mathrm{dm}^{-3}\right): 5.4 ;$ P-resin $(\mathrm{mg}$ $\left.\mathrm{dm}^{-3}\right)$ : 6.8; effective CEC $\left(\mathrm{mmol}_{\mathrm{c}} \cdot \mathrm{dm}^{-3}\right): 15.0$; CEC to pH $7.0\left(\mathrm{mmol}_{\mathrm{c}} \mathrm{dm}^{-3}\right): 51.0$; BS (\%): 12.0; m (\%): 60.0; Organic matter $\left(\mathrm{g} \mathrm{kg}^{-1}\right): 17.0 ; \mathrm{B}\left(\mathrm{mg} \mathrm{dm}^{-3}\right): 0.3 ; \mathrm{Cu}\left(\mathrm{mg} \mathrm{dm}^{-3}\right): 1.0 ; \mathrm{Fe}\left(\mathrm{mg} \mathrm{dm}^{-3}\right): 60.2 ; \mathrm{Mn}\left(\mathrm{mg} \mathrm{dm}^{-3}\right): 6.4 ; \mathrm{Zn}$ $\left(\mathrm{mg} \mathrm{dm}^{-3}\right): 0.1$; Coarse sand $\left(\mathrm{g} \mathrm{kg}^{-1}\right): 470.0$; Fine sand $\left(\mathrm{g} \mathrm{kg}^{-1}\right): 460.0$; Silt $\left(\mathrm{g} \mathrm{kg}^{-1}\right): 10.0$; Clay $\left(\mathrm{g} \mathrm{kg}^{-1}\right): 60.0 ; \mathrm{SiO}_{2}$ $\left(\mathrm{g} \mathrm{kg}^{-1}\right): 31.0 ; \mathrm{Al}_{2} \mathrm{O}_{3}\left(\mathrm{~g} \mathrm{~kg}^{-1}\right): 36.0 ; \mathrm{Fe}_{2} \mathrm{O}_{3}\left(\mathrm{~g} \mathrm{~kg}^{-1}\right): 11.0 ; \mathrm{TiO}_{2}\left(\mathrm{~g} \mathrm{~kg}^{-1}\right): 5.0 ; \mathrm{P}_{2} \mathrm{O}_{5}\left(\mathrm{~g} \mathrm{~kg}^{-1}\right): 0.0 ; \mathrm{Fe}_{\mathrm{d}}\left(\mathrm{g} \mathrm{kg}^{-1}\right): 2.0$; $\mathrm{Fe}_{\mathrm{o}}\left(\mathrm{g} \mathrm{kg}^{-1}\right): 0.1 ; \mathrm{Ct}\left(\mathrm{g} \mathrm{kg}^{-1}\right): 778.0 ; \mathrm{Gb}\left(\mathrm{g} \mathrm{kg}^{-1}\right): 59.0$.

The experimental design was a completely randomized design, in a $4 \times 3$ factorial scheme with four replicates and four P rates $\left(0,80,240\right.$ and $\left.410 \mathrm{mg} \mathrm{dm}^{-3}\right)$, defined as a function of the remaining P (Alvarez, Novais, Dias, \& Oliveira, 2000) and three evaluation times (before sowing-BS, after harvest-AH, and incubated soil without plant-INC).

The soil samples contained in the pots $\left(5 \mathrm{dm}^{-3}\right)$ were submitted to two sequential applications (limestone and fertilization). After each application, the soil was incubated for a period of 30 days under a humidity equivalent to $60 \%$ of the total pore volume (TPV) occupied by water (Freire, Ribeiro, Bahia, Lopes, \& Aquino, 1980) deionized, controlled by daily weighing. The first application was made with micro-powdered calcined dolomitic limestone $(35 \% \mathrm{CaO}$ and $14 \% \mathrm{MgO})$ in the amount indicated to raise the base saturation value to $50 \%$. The second application consisted of the application of $\mathrm{P}$ doses together with basic fertilization, which corresponded to the following nutrient contents in the form of PA salts per $\mathrm{dm}^{3}$ of soil: $100 \mathrm{mg}$ of N; $150 \mathrm{mg} \mathrm{K} ; 62 \mathrm{mg}$ of S; $0.81 \mathrm{mg}$ of $\mathrm{B} ; 1.3 \mathrm{mg}$ of $\mathrm{Cu} ; 5.0 \mathrm{mg} \mathrm{Zn} ; 3.6 \mathrm{mg}$ of $\mathrm{Mn} ; 1.6 \mathrm{mg}$ of Fe, and $0.15 \mathrm{mg}$ of Mo. Nutrients were applied as a solution and mixed to the soil for further standardization.

Thirty days after the second application ( $\mathrm{P}$ doses and base fertilization), soil subsamples from each pot were collected for sequential extraction of soil phosphorus fractions (P-resin, $\mathrm{Pi}-\mathrm{NaHCO}_{3} ; \mathrm{Po}-\mathrm{NaHCO}_{3} ; \mathrm{Pi}-\mathrm{NaOH} 0.1$; Po-NaOH 0.1; Pi-NaOH 0.5; Po-NaOH 0.5; P-HCl, and P-residual), according to the method by Hedley et al. (1982) and incubated for another 90 days (soil amount incubated-50 g). Samples were conditioned in plastic cups inside the greenhouse, under the condition of humidity equivalent to $60 \%$ of the TPV occupied by water (Freire et al., 1980). 
The rest of the soil in each pot was cultivated with rice (Oryza sativa L., cv. Primavera). Seven rice seeds were sown per pot. Thinning was done after 20 days, leaving two plants per pot. The soil moisture was maintained at the equivalent to $60 \%$ of the TPV occupied by water (Freire et al., 1980).

After harvesting the rice and incubating the soil for another 90 days, soils were collected, dried, crushed, sieved through a 2-mm mesh sieve, and subjected to sequential extraction of the soil phosphorus fractions, according to the method by Hedley et al. (1982).

The $\mathrm{P}$ forms determined in soil were: (1) labile $\mathrm{P}$ forms, that is, available $\mathrm{P}\left(\mathrm{P}_{\mathrm{RTA}}\right)$ - resin, and $\mathrm{P}$ adsorbed to the surface of colloids $\left[\left(\mathrm{Pi}_{\mathrm{BIC}}+\mathrm{Po}_{\mathrm{BIC}}\right)-\mathrm{NaHCO}_{3} 0.5 \mathrm{~mol} \mathrm{~L}^{-1}\right]$; (2) poorly labile $\mathrm{P}$ sources, comprising inorganic $\mathrm{P}$ bound to $\mathrm{Fe}$ and $\mathrm{Al}$, and organic $\mathrm{P}$ bound to humic compounds $\left[\left(\mathrm{Pi}_{\mathrm{NaOH} 0.1 \text { and } 0.5}+\mathrm{Po}_{\mathrm{NaOH} 0.1 \text { and } 0.5}\right)-\mathrm{NaOH} 0.1\right.$ and $0.5 \mathrm{~mol} \mathrm{~L}^{-1}$ ]; and (3) non-labile forms of $\mathrm{P}$, which include Ca-linked $\mathrm{P}\left(\mathrm{P}_{\mathrm{HCl}}\right)$, extracted with $1 \mathrm{~mol} \mathrm{~L}^{-1} \mathrm{HCl}$, and the more stable forms of $\mathrm{Po}$ and $\mathrm{Pi}\left(\mathrm{P}_{\text {residual }}\right)$, determined by digestion with concentrated $\mathrm{H}_{2} \mathrm{SO}_{4}$, and $\mathrm{H}_{2} \mathrm{O}_{2}$.

All the data were submitted to a variance analysis (ANOVA). When significant differences were found among $\mathrm{P}$ doses and interaction between evaluation time and $\mathrm{P}$ doses, regression studies were performed. These analyses were performed using the ASSISTAT software (Silva \& Azevedo, 2016).

\section{Results and Discussion}

\subsection{Inorganic phosphorus fractions}

The soil inorganic $\mathrm{P}$ includes fractions extracted with resin $\left(\mathrm{P}_{\mathrm{RTA}}\right)$, bicarbonate $\left(\mathrm{Pi}_{\mathrm{bic}}\right)$, sodium hydroxide $\left(\mathrm{Pi}_{\mathrm{NaOH}}\right)$, and hydrochloric acid $\left(\mathrm{P}_{\mathrm{HCl}}\right)$.

Phosphorus application provided a linear increase $(p<0.01)$ in the contents of $\mathrm{Pi}$ in almost all inorganic fractions (Figures $1 \mathrm{~A}, 1 \mathrm{~B}, 1 \mathrm{C}$, and 1E), except for $\mathrm{Pi}_{\mathrm{NaOHO5}}$ (Figure 1D), which fitted the quadratic regression model ( $\mathrm{p}<$ 0.01 ), with $1.53 ; 2.21$, and $26.11 \mathrm{mg} \mathrm{dm}^{-3}$ of $\mathrm{Pi}_{\mathrm{NaOH} 05}$ when the doses of $130 ; 247.5$, and $181.33 \mathrm{mg} \mathrm{dm}^{-3}$ of $\mathrm{P}$ were added, respectively, before sowing (BS), after harvest (AH), and when the soil was incubated (INC).

The contribution of the phosphate fertilizer to the Pi was higher in the fractions considered available $\left(\mathrm{P}_{\mathrm{RTA}}\right.$ and $\mathrm{Pi}_{\mathrm{BIC}}$ ), followed by the $\mathrm{Pi}_{\mathrm{NaOH} 01}$ fraction. The contribution the phosphate fertilization was small in the total $\mathrm{P}$ for the $\mathrm{P}_{\mathrm{HCl}}$ fraction, even with the linear increase of this fraction with the increase in $\mathrm{P}$ doses, which indicates that very little fertilizer accumulated in this fraction.

Soil incubation favored the accumulation of the inorganic fractions extracted with $\mathrm{NaHCO}_{3}, \mathrm{NaOH} 0.1, \mathrm{NaOH}$ 0.5 , and $\mathrm{HCl}$, indicating that the contact time of phosphate with the soil favors the conversion of the P released from the fertilizer to all $\mathrm{P}$ inorganic fractions (Figures 1B, 1C, 1D, and 1E). The data obtained in this study can be attributed to the soil mineralogy, which presents low concentrations of $\mathrm{Fe}$ and $\mathrm{Al}$ oxides $\left(11.0 \mathrm{~g} \mathrm{~kg}^{-1}\right.$ and 35.8 $\mathrm{g} \mathrm{kg}^{-1}$ ) and high kaolinite content $\left(778.0 \mathrm{~g} \mathrm{~kg}^{-1}\right)$. This actively contributes to providing nutrients to plants, however, the $\mathrm{P}$ in these fractions can potentiate transfer through the solution of the soil drained on the soil surface or percolated in the profile, representing a potential for water contamination (Schmitt et al., 2014).

All Pi fractions are observed to decrease after rice cultivation (Figures 1A, 1B, 1C, and 1E), except for the fraction $\mathrm{Pi}_{\mathrm{NaOHO.5}}$ (Figure 1D), indicating that practically all fractions contributed to rice plant nutrition. However, the linear adjustment of Pi fraction data, even in the $\mathrm{AH}$ period after rice cultivation (Figures 1A, 1B, 1C, and $1 \mathrm{E})$, allows inferring that the contents of these fractions are directly related to the $\mathrm{P}$ doses applied, what points to a saturation process of the adsorption sites (Conte, Anghinoni, \& Rheinheimer, 2003). This reinforces the idea that the amount of phosphorus added exceeds the plant demand and, therefore, part of this $\mathrm{P}$ can be drained at the soil surface or percolated in the profile.

\subsection{Organic Phosphorus Fractions}

Organic P forms are very important for the mineralization and dynamics of availability of Pi forms (Tiecher, Rheinheimer, \& Calegari, 2012). The soil organic $\mathrm{P}$ includes the fractions extracted with bicarbonate $\left(\mathrm{Po}_{\mathrm{BIC}}\right)$ and sodium hydroxide $\left(\mathrm{Po}_{\mathrm{NaOH}} 0.1\right.$ and 0.5). The lowest Po contents were found in the $\mathrm{Po}_{\mathrm{BIC}}$ fraction (Figure 2A). This fraction corresponds to the most unstable Po fraction and is accessible to microorganisms, which can be made available to plants more easily (Leite, Cruz, Ferreira, Andrioli, \& Braos, 2016).

$\mathrm{Po}_{\mathrm{BIC}}$ contents were adjusted to quadratic models $(\mathrm{p}<0.01)$, with minimum values of $9.0 ; 15.0$, and $4.0 \mathrm{mg} \mathrm{dm}^{-3}$ at doses of 150,110 , and $140 \mathrm{mg} \mathrm{dm}^{-3}$ of $\mathrm{P}$, respectively, before sowing (BS), after harvest (AH), and after incubation (INC) (Figure 2A). The fractions $\mathrm{Po}_{\mathrm{NaOH} 0.1}$ and $\mathrm{Po}_{\mathrm{NaOH}} 0.5$ before sowing (BS) are observed to present adjustments of the quadratic equations through regression analysis in the doses of 124 and $167 \mathrm{mg} \mathrm{dm}^{-3}$, with contents of 34 and $32 \mathrm{mg} \mathrm{dm}^{-3}$ for the fractions $\mathrm{Po}_{\mathrm{NaOH} 0.1}$ and $\mathrm{Po}_{\mathrm{NaOH}} 0.5$, respectively (Figures $2 \mathrm{~B}$ and $2 \mathrm{C}$ ). The variations observed between the fractions $\mathrm{Po}_{\mathrm{NaOH}} 0.1$ and $\mathrm{Po}_{\mathrm{NaOH}} 0.5$ allow us to assume that $\mathrm{P}$ fertilization 
increased the organic $\mathrm{P}$ mineralization by soil microorganisms, increasing the more labile fractions of $\mathrm{P}\left(\mathrm{P}_{\mathrm{RTA}}\right.$ and $\left.\mathrm{Pi}_{\mathrm{BIC}}\right)$, and that part of the Pi generated was re-adsorbed, replacing the labile $\mathrm{P}$ fractions, and part was remobilized and transformed into $\mathrm{Po}_{\mathrm{NaOH}} 0.1$ and 0.5 .

In general, the highest Po levels in soils were found after rice cultivation (AH) (Figures 2A, 2B, and 2C); therefore, there was a lack of organic P depletion with cultivation. Such result indicates that Pi absorption by plants did not trigger Po mineralization and the inorganic fraction acted as a source of P, replacing the soil solution. Thus, the organic fractions were not very participative when a great availability of the most labile inorganic fractions occurred. Concomitantly, soil cultivation promotes greater organic matter accumulation when compared to the incubated soil and higher microbial biomass activity, which may result in the formation of $\mathrm{P}$ complexes with humic substances, acting as a phosphate drain (Redel, Rubio, Rouanet, \& Borie, 2007). This would mean the highest values obtained for both fractions of organic P in soils after harvest when compared to soil BS and INC.
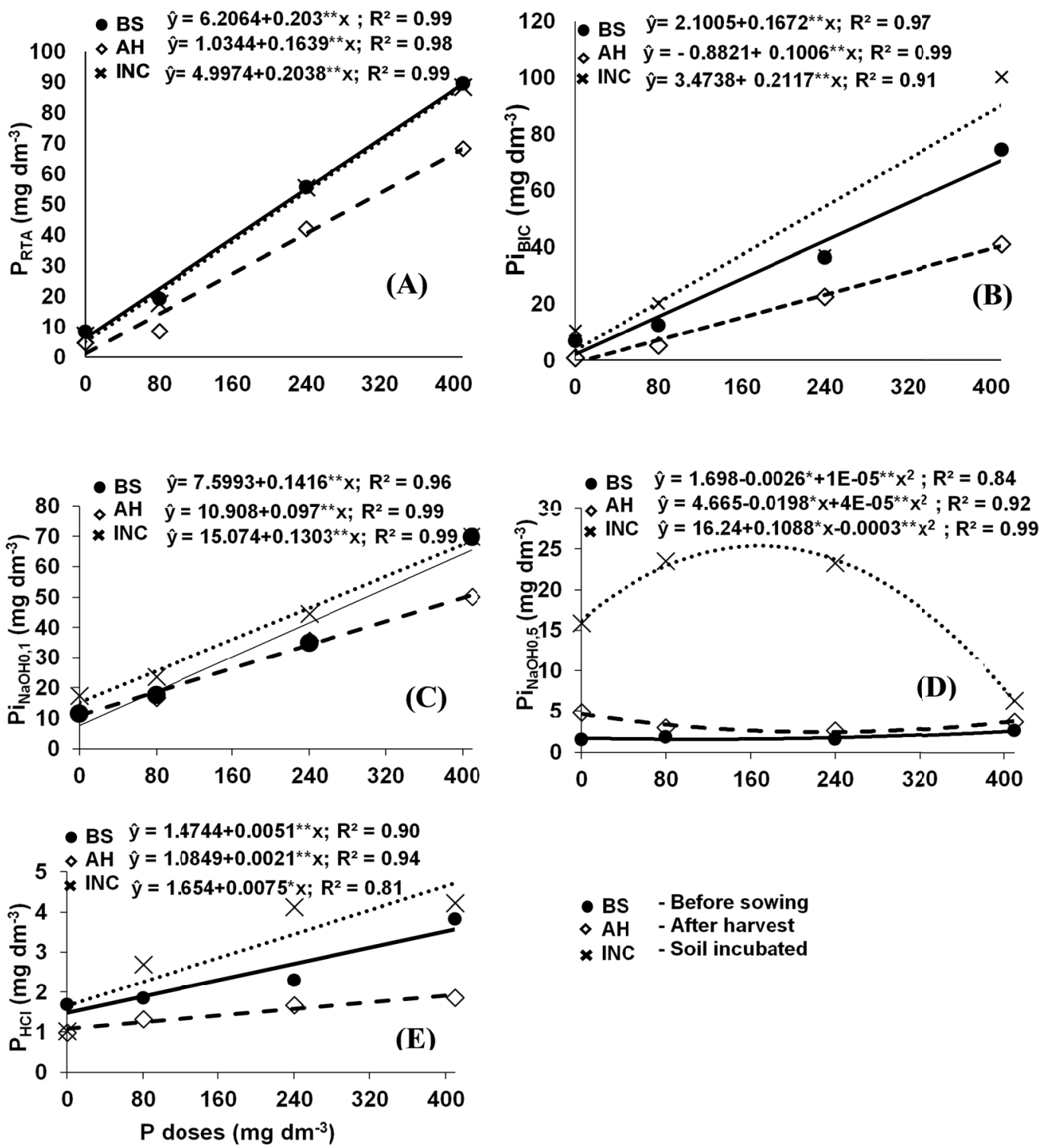

Figure 1. Soil phosphorus content in inorganic fractions, as a function of $\mathrm{P}$ doses and evaluation time (BS, AH, and INC). (A) $\mathrm{P}_{\text {RTA }}$ (P extracted with resin), (B) $\mathrm{Pi}_{\mathrm{BIC}}$ (Pi extracted with $\mathrm{NaHCO}_{3} 0.5 \mathrm{~mol} \mathrm{~L}^{-1}$ ), (C) $\mathrm{Pi}_{\mathrm{NaOH} 0.1}(\mathrm{Pi}$ extracted with $\mathrm{NaOH} 0.1 \mathrm{~mol} \mathrm{~L}^{-1}$ ), D) $\mathrm{Pi}_{\mathrm{NaOH} 0.5}\left(\mathrm{Pi}\right.$ extracted with $\mathrm{NaOH} 0.5 \mathrm{~mol} \mathrm{~L}^{-1}$ ), and (E) $\mathrm{P}_{\mathrm{HCl}}(\mathrm{P}$ extracted with $\left.\mathrm{HCl} 1.0 \mathrm{~mol} \mathrm{~L}^{-1}\right)$. $*$ and **: significant at 5 and $1 \%$ probability, respectively 
In addition, if the soil is cultivated, substantial amounts of plant residue is deposited annually in the soil, resulting in a greater transformation of inorganic $\mathrm{P}$ into organic $\mathrm{P}$ fractions of different weights. Furthermore, the annual use of phosphate fertilizers causes $\mathrm{P}$ to accumulate in the soil in inorganic forms, causing the $\mathrm{P}$ buffering of the soil solution, which decreases the use of the organic fraction of this nutrient, allowing it to accumulate. This is because the amounts of $\mathrm{P}$ added to the soil as fertilizers are higher than are those exported by the grains (Novais \& Smith, 1999). The organic compartment of $\mathrm{P}$ might represent a $\mathrm{P}$ drain when the element is found in high contents in the soil, as well as being a source of $\mathrm{P}$ for plants in deficient situations.
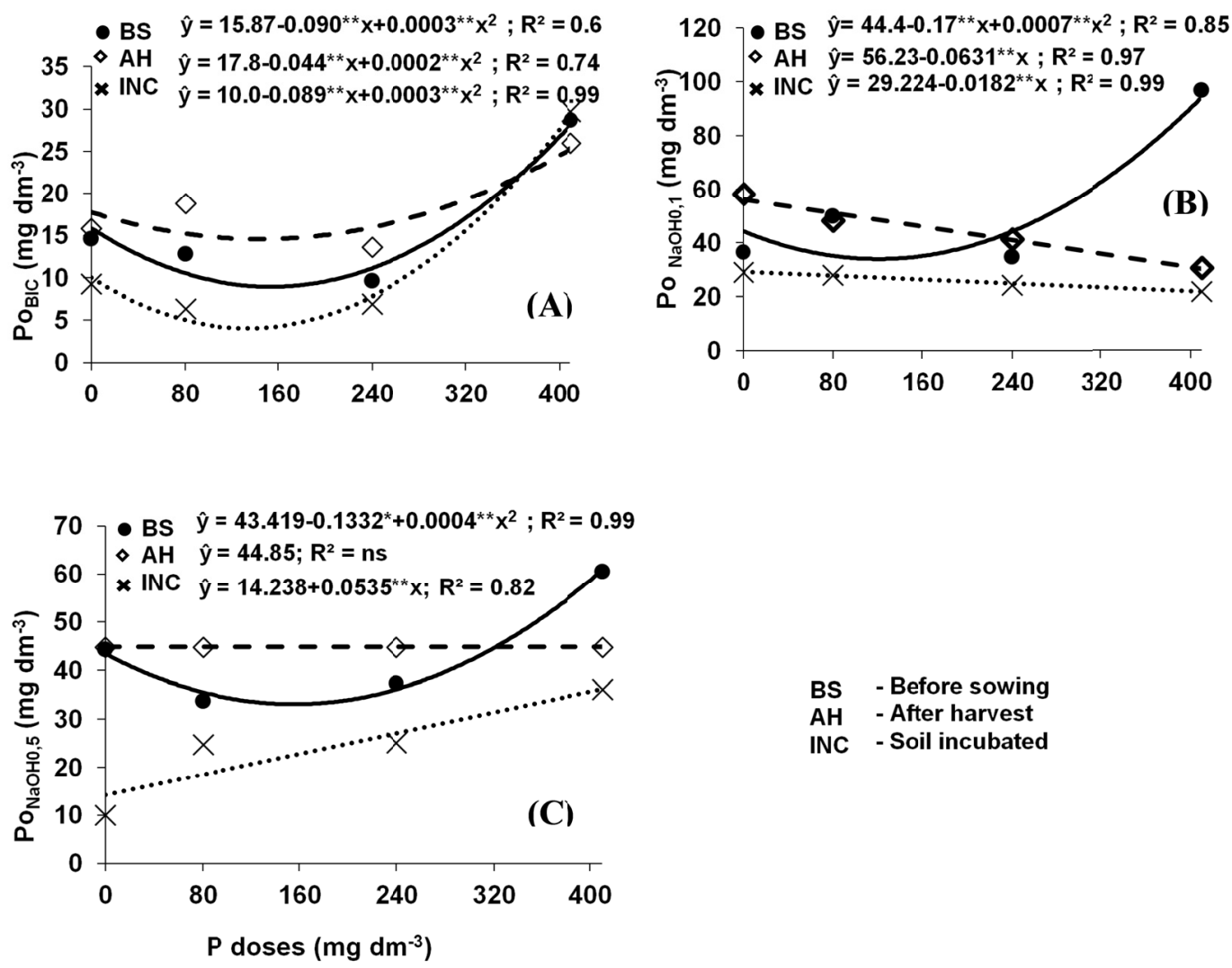

Figure 2. Phosphorus content in soil, in organic fractions, as a function of $\mathrm{P}$ doses and evaluation time (BS, AH, and INC). (A) $\mathrm{Po}_{\mathrm{BIC}}$ (Po extracted with $\mathrm{NaHCO}_{3} 0.5 \mathrm{~mol} \mathrm{~L}^{-1}$ ), (B) $\mathrm{Pi}_{\mathrm{NaOH} 0.1}$ (Po extracted with $\mathrm{NaOH} 0.1 \mathrm{~mol}$ $\left.\mathrm{L}^{-1}\right),(\mathrm{C}) \mathrm{P}_{\mathrm{oNaOH} 0.5}\left(\mathrm{Po}\right.$ extracted with $\left.\mathrm{NaOH} 0.5 \mathrm{~mol} \mathrm{~L}^{-1}\right)$.* and **: significant at 5 and $1 \%$ probability, respectively

\subsection{Residual Phosphorus of Pi and Po Ratio in Relation to Total Soil P}

The residual fraction obtained through soil acid digestion is composed of non-extracted $\mathrm{P}$ by the selective extractors of the Hedley fractionation, being composed of fractions of recalcitrant Pi and Po. The P content in this fraction was low compared to the other fractions, indicating that this soil presents low adsorption and that a great part of the $\mathrm{P}$ is in forms of low connection energy with soil colloids. $\mathrm{P}_{\text {residual }}$ contents presented no significant difference with the addition of $\mathrm{P}$ and evaluation times, presenting average contents of 22.71, 20.67, and $15.37 \mathrm{mg} \mathrm{dm}^{-3}$, which indicates that the $\mathrm{P}$ added was preferentially accumulated in the fractions of higher lability, confirming the low phosphate adsorption capacity in this $\mathrm{P}$ fraction.

The study of the contribution of Pi and Po to the total soil P BS, AH, and INC shows a predominance of the Pi fraction compared to the Po fraction, regardless of the evaluation time (BS, AH, and INC) (Figures 3A and 3B), suggesting that $\mathrm{Pi}$ is the form of accumulation in sandy soils which receive phosphate fertilizers. Comparable results have been suggested by other authors, who observed that the addition of phosphate fertilizers to soil results in a more pronounced accumulation of $\mathrm{P}$ in inorganic fractions, with different degrees of binding energy (Santos et al., 2008; Pavinato, Merlin, \& Rosolem, 2009; Alovisi et al., 2016). Santos et al. (2008) reported that the participation of the $\mathrm{P}$ organic compartment is more expressive for soils with higher clay content when 
compared to the inorganic, but in sandy soils, the behavior of Po and Pi depends on the previous soil management.

Phosphorus application resulted in a linear increase in the Pi contents after harvest $(\mathrm{AH})$, confirming that the rice plants absorbed part of the inorganic P (Figures 1A, 1B, 1C, and 1D) and that the amounts added exceed plant demand. After sowing (AS) and after incubation (INC), the percentages of Pi relative to total $\mathrm{P}$ were adjusted to the quadratic regression model $(\mathrm{p}<0.01)$, with $\mathrm{P}$ doses with maximum values of 68.63 and $80.76 \%$ of $\mathrm{Pi}$, at the doses of 343.33 and $369.25 \mathrm{mg} \mathrm{dm}^{-3}$ of P, respectively, BS and INC (Figure 3A). After incubation, the contents of Pi represented 53.49 to $80.76 \%$ of the total P extracted (Figure 3A).
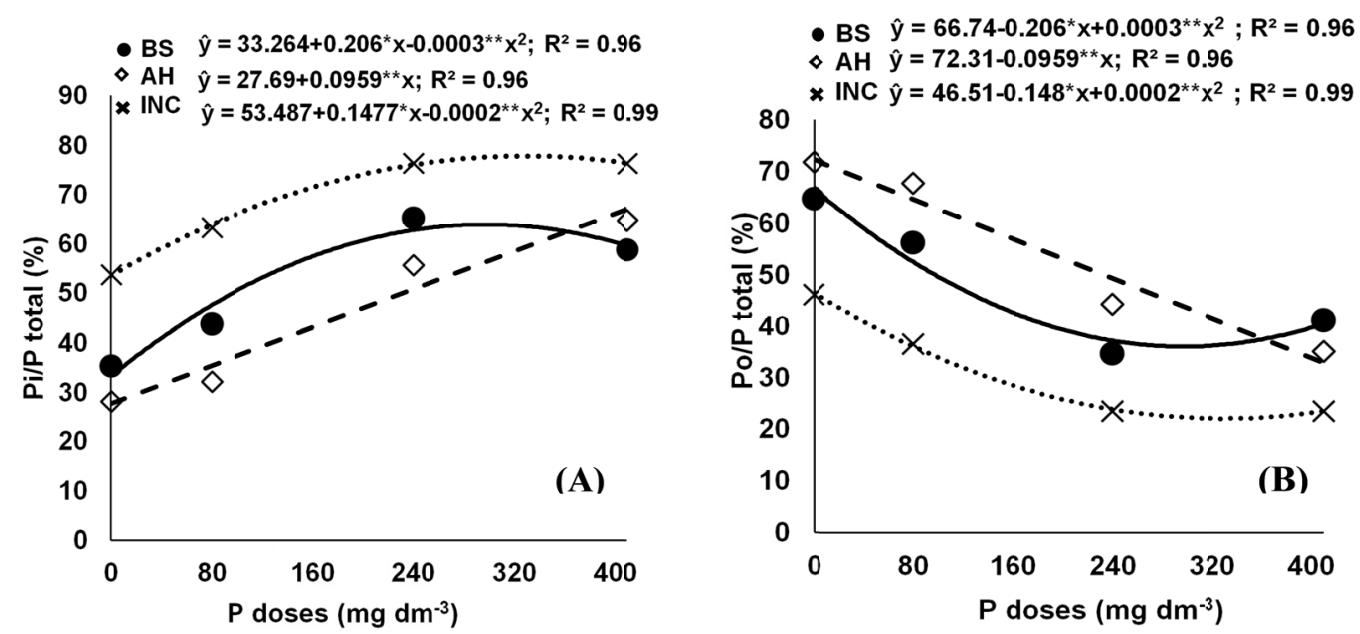

Figure 3. Percentage distribution of the total fractions of inorganic and organic phosphorus in the soil, as a function of $\mathrm{P}$ doses and evaluation time (BS, AH, and INC). (A) Pi/Ptotal: percentage of inorganic phosphorus in relation to total phosphorus, (B) Po/Ptotal: percentage of organic phosphorus in relation to total phosphorus. $*$ and ${ }^{* *}$ : significant at 5 and $1 \%$ probability, respectively

In the three evaluation times, for Po in relation to total $\mathrm{P}$, the percentage of the organic fractions decreased with the increase of $\mathrm{P}$ doses (Figure $3 \mathrm{~B}$ ), that is, the addition of phosphate fertilizers triggered the Po mineralization process. The Po percentage of the soil collected after the rice cultivation reduced linearly, while the soils collected BS and INC presented minimum points of 31.37 and $19.24 \%$ of the Po/Ptotal ratio, in the doses of 343.33 and $369.25 \mathrm{mg} \mathrm{dm}^{-3}$ of $\mathrm{P}$ (Figures 3B). Mean values of $30 \%$ are found in many tropical regions, in different soil classes (Xavier, Almeida, Cardoso, \& Mendonça, 2011; Oliveira et al., 2014, Costa et al., 2016). In the soil after rice cultivation (AH), even with the addition of the highest added dose of P $\left(410 \mathrm{mg} \mathrm{dm}^{-3}\right)$, the percentage of $\mathrm{Po} / \mathrm{Ptotal}$ is above $30 \%$. These results suggest that there is a need to maintain the sandy soil with vegetation that provides a large amount of organic matter, to maintain or increase the proportion of organic $P$.

As $\mathrm{P}$ doses increased, a higher participation of PiL in Plabile was observed, and an inverse behavior was noted for PoL (Figures 4A and 4B), where the highest participation of PoL was found in soils with no phosphate fertilization (Figure 4B). Regardless of the evaluation time (BS, AH, and INC), most of the phosphate applied was converted to Pi. Higher Pi levels in the labile compartment may represent a risk of contamination of water bodies by phosphorus. 

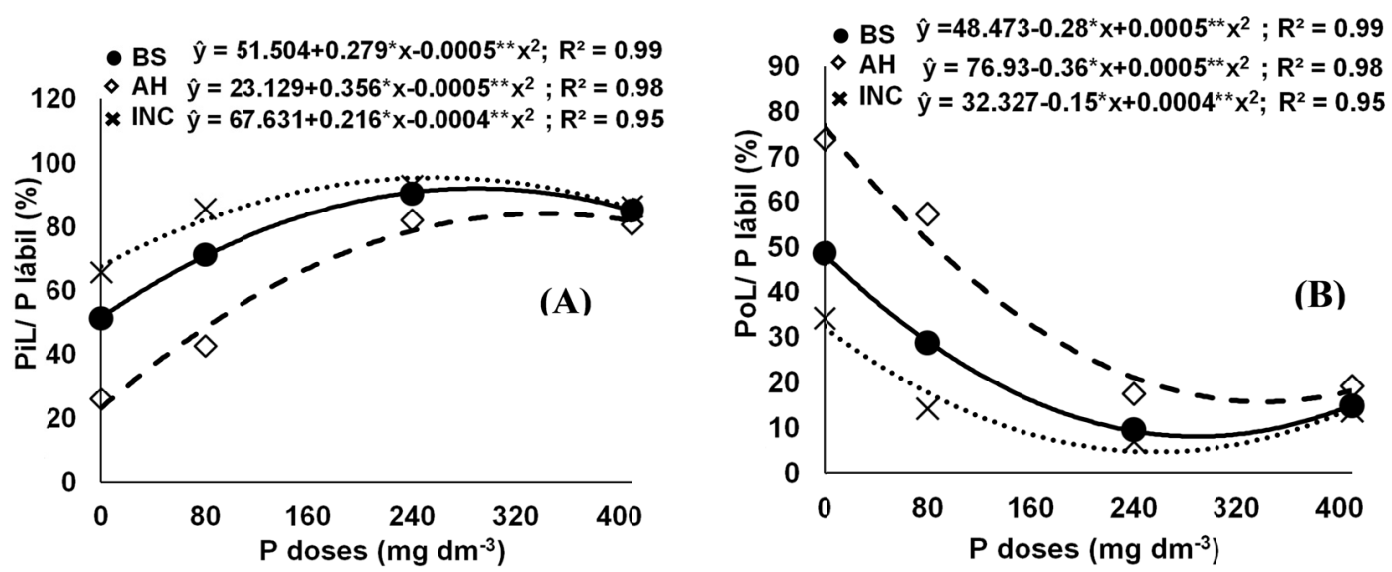

Figure 4. Percentage distribution of the labile fractions of inorganic and organic phosphorus in the soil, as a function of $\mathrm{P}$ doses and evaluation time (BS, AH, and INC). (A) PiL/Plabile: percentage of labile inorganic phosphorus in relation to total labile phosphorus, (B) PoL/Plabile: percentage of labile organic phosphorus in relation to total labile phosphorus. * and **: significant at 5 and $1 \%$ probability, respectively

\section{Conclusions}

Phosphorus fractions were influenced by the soil collection times. The inorganic fractions prevailed before sowing and after incubation, and the organic fractions prevailed after the harvest.

Phosphate fertilization favors the mineralization of organic $\mathrm{P}$ and redistributes the inorganic and organic $\mathrm{P}$ fractions between labile and non-labile compartments.

The application of phosphate fertilizer in Entisol Quartzipsamment contributes to the accumulation of inorganic fractions, especially in the most labile fractions.

\section{References}

Alovisi, A. M. T., Furtini Neto, A. E., Carneiro, L. F., Curi, N., Santos, J. Z. L., \& Alovisi., A. A. (2011). Dinâmica das formas de fósforo em solos de textura e mineralogia contrastantes cultivadas com arroz. Acta Scientiarum, Agronomy, 33, 171-179.

Alovisi, A. M. T., Furtini Neto, A. E., Serra, A. P., Alovisi, A. A., Tokura, L. K., Lourente, E. R. P., Silva, R. S., Silva, C. F. B., \& Fernandes, J. S. (2016). Phosphorus and silicone fertilizers rates effects on dynamic of soil phosphorus fractions in oxisol under common bean cultivation. African jornal of Agricultural Research, 30, 2697-2707.

Alovisi, A. M. T., Serra, A. P., Alovisi, A. A., Tokura, L. K., Lourente, E. R. P., Carneiro, L. F., ... Silva, R. S. (2018). Dynamic of phosphorus fractions in typic Quartzipsamment soil cropped with bean. Journal of Agricultural Science, 10(9), 493-503. https://doi.org/10.5539/jas.v10n9p493

Alvarez, V. H., Novais, R. F., Dias, L. E., \& Oliveira, J. A. (2000). Determinação e uso do fósforo remanescente. Boletim Informativo da Sociedade Brasileira de Ciência do Solo, 25, 27-32.

Claessen, M. E. C. (1997). Manual de Métodos de Análise de Solo (2nd ed., p. 212). Rio de Janeiro: EMBRAPA-CNPS.

Conte, E., Anghinoni, I., \& Rheinheimer, D. S. (2003). Frações de fósforo acumuladas em Latossolo argiloso pela aplicação de fosfato no sistema plantio direto. Revista Brasileira de Ciência do Solo, 27, 893-900. https://doi.org/10.1590/S0100-06832003000500014

Costa, M. G., Gama-Rodrigues, A. C., Gonçalves, J. L. M., Gama-Rodrigues, E. F., Sales, M. V. S., \& Aleixo, S. (2016). Labile and non-labile fractions of phosphorus and its transformations in soil under eucalyptus plantations, Brazil. Forests, 7, 15. https://doi.org/10.3390/f7010015

Freire, J. C., Ribeiro, M. A., Bahia, V. G., Lopes, A. S., \& Aquino, L. H. (1980). Resposta do milho cultivado em casa de vegetação a níveis de água em solos da região de Lavras (MG). Revista Brasileira de Ciência do Solo, 4, 5-8. 
Hedley, M. J., Stewart, J. W. B., \& Chauhan, B. S. (1982). Changes in inorganic soil phosphorus fractions induced by cultivation practices and laboratory incubations. Soil Science Societyof America Journal, 46, 970-976. https://doi.org/10.2136/sssaj1982.03615995004600050017x

Kluthcouski, J., \& Cordeiro, L. A. M. (2016). Produção sustentável nos solos arenosos. Retrieved from http://www.solosarenosos.com.br/detalhes-noticia/producao-sustentavel-nos-solos-arenosos

Leite, J. N. F., Cruz, M. C. P., Ferreira, M. E., Andrioli, I., \& Braos, L. B. (2016). Frações orgânicas e inorgânicas do fósforo no solo influenciadas por plantas de cobertura e adubação nitrogenada. Pesquisa Agropecuária Braileira, 51, 1880-1889. https://doi.org/10.1590/s0100-204×2016001100010

Mehra, O. P., \& Jakson, N. L. (1960). Iron oxide removal from soils and clays by a dithionite-citrate system buffered with sodium bicarbonate. Clays Clay Miner, 3, 317-327.

Novais, R. F., \& Smyth, T. J. (1999). Fósforo em solo e planta em condições tropicais (p. 399). Viçosa: Universidade Federal de Viçosa.

Oliveira, R. I., Gama-Rodrigues, A. C., Gama-Rodrigues, E. F., Zaia, F. C., Pereira, M. G., \& Fontana, A. (2014). Organic phosphorus in diagnostic surface horizons of ifferent Brazilian soil orders. Revista Brasileira de Ciência do Solo, 38, 1411-1420. https://doi.org/10.1590/S0100-06832014000500006

Pavinato, P. S., Merlin, A., \& Rosolem, C. A. (2009). Phosphorus fractions in Brazilian Cerrado soils as affected by tillage. Soil \& Tillage Research, 105, 149-155. https://doi.org/10.1016/j.still.2009.07.001

Raij, B. V., \& Feitosa, C. T. (1980). Correlação entre o P extraído de solo por diversos extratores químicos extratores químicos e o absorvido pelo milho. Bragantia, 39, 51-57. https://doi.org/10.1590/S0006-8705 1980000100007

Redel, Y. H., Rubio, R., Rouanet, J. L., \& Borie, F. (2007). Phosphorus bioavailability affected by tillage and crop rotation on a Chelean volvanic derived Ultisol. Geoderma, 139, 388-396. https://doi.org/10.1016/ j.geoderma.2007.02.018

Santos, J. Z. L., Furtini Neto, A. E., Resende, A. V., Curi, N., Carneiro, L. F., \& Costa, S. E. V. G. A. (2008). Frações de fósforo em solo adubado com fosfatos em diferentes modos de aplicação e cultivado com milho. Revista Brasileira de Ciencia do Solo, 32, 705-714. https://doi.org/10.1590/S0100-06832008000200025

Schmitt, D. E., Gabitoni, L. C., Girotto, E., Lorensini, F., Melo, G. W., \& Brunetto, G. (2014). Phosphorus fractions in the vineyard soil of the Serra Gaúcha os Rio Grande do Sul, Brazil. Revista Brasileira de Engenharia Agricola e Ambiental, 18, 134-140. https://doi.org/10.1590/S1415-43662014000200002

Schwertman, U., Kodama, H., \& Fisher, W. R. (1986). Mutual interactions between organics and iron oxides. In P. M. Huang, \& M. Schnitzer (Eds.), Interaction of soil minerals with natural organics and microbes (pp. 309-330). Madison: SSSA.

Silva, F. A. S., \& Azevedo, C. A. V. (2016). The Assistat Software version 7.7 and its use in the analysis of experimental. African Journal of Agricultural Research, 11, 3733-3740. https://doi.org/10.5897/AJAR2016. 11522

Soil Survey Staff. (2014). Keys to soil taxonomy (12th ed.). Washington, DC: USDA-Natural Resources Conservation Service.

Spera, S. T., Reatto, A., Martins, E. S., Correia, J. R., \& Cunha, T. J. F. (1999). Solos areno-quartzosos do Cerrado: características, problemas e limitações ao uso (p. 48). Planaltina: Embrapa-CPAC.

Tiecher, T., Rheinheimer, D. S., \& Calegari, A. (2012). Soil organic phosphorus forms under different soil management systems and winter crops, in a long term experiment. Soil \& Tillage Research, 124, 57-67. https://doi.org/10.1016/j.still.2012.05.001

Turner, B. L., Cade-Menun, B. J., Condron, L. M., \& Newman, S. (2005). Extraction of organic soil phosphorus. Talanta, 66, 294-306. https://doi.org/10.1016/j.talanta.2004.11.012

Xavier, F. A. S., Almeida, E. F., Cardoso, I. M., \& Mendonça, E. S. (2011). Soil phosphorus distribuition in sequentially extracted fractions in tropicl coffee-agroecosystems in the Athantic Forest biome, Southeastem Brazil. Nutrient Cycling in Agroecosystems, 89, 31-44. https://doi.org/10.1007/s10705-010-9373-5 


\section{Copyrights}

Copyright for this article is retained by the author(s), with first publication rights granted to the journal.

This is an open-access article distributed under the terms and conditions of the Creative Commons Attribution license (http://creativecommons.org/licenses/by/4.0/). 